\title{
Erratum to: Hard Problems of Intentionality
}

\section{Mark Rowlands ${ }^{1}$}

Published online: 2 February 2016

(C) Springer Science+Business Media Dordrecht 2016

\section{Erratum to: Philosophia (2015) 43:741-746 \\ DOI 10.1007/s11406-015-9626-2}

The original version of this article unfortunately contained a mistake. The name of the author was not properly spelled. The correct spelling is presented above.

The online version of the original article can be found at http://dx.doi.org/10.1007/s11406-015-9626-2.

\section{Mark Rowlands}

mrowlands@miami.edu

1 Department of Philosophy, University of Miami, Coral Gables, FL 33124, USA 